\title{
Networks of Exchange in Anglo-Portuguese Sixteenth-Century Diplomacy and Thomas Wilson's Mission to Portugal
}

\author{
Susana Oliveira
}

Alas, how should you govern any kingdom

That know not how to use ambassadors?

W. SHAKESPEARE, Henry VI, Part 3 (IV.3.35-36)

The Anglo-Portuguese Alliance is usually mentioned as one of the longest in history, dating back to the thirteenth century, conveying multiple networks of exchange: geopolitical strategies, trade policies, dynastic marriages and diplomatic negotiations.*,1 Nonetheless, Portugal was also close (perhaps too close from Elizabeth I's perspective) to the Hispanic Monarchy of the Habsburg in a context of great antagonism between Elizabeth I and Philip II. First, the two Iberian nations shared the dominion of the seas and the great enterprise of the sea explorations (as confirmed by the Treaty of Tordesillas and the Treaty of Zaragoza). Second, they were neighbouring powers with a policy of royal marriages to strengthen their Iberian power (in the three generations before the birth of D. Sebastião, eight of the eleven marriages of the Portuguese royal house were performed in Castile), ${ }^{2}$ the most relevant for the purpose of this

* Abbreviations: ANTT = Arquivo Nacional da Torre do Tombo, Lisbon; BL = British Library, London; SP = Kew, The National Archives, Public Record Office, State Papers; SPF = Kew, The National Archives, Public Record Office, State Papers Foreign.

1 Attreed L., "Friends in Need or in Deed? Anglo-Portuguese Relations in the Fifteenth Century", Mediterranean Studies 8 (1999) 143-156; Chapman A.B.W., "The Commercial Relations of England and Portugal, 1487-1807", Transactions of the Royal Historical Society 1 (1907) 157-179; Shaw L.M.E., The Anglo-Portuguese Alliance and the English Merchants in Portugal, 1654-1810 (Aldershot: 1998).

2 Such policy of royal marriages between the crowns of Portugal and Castile became a crucial factor for the Union of the Crowns in 1580. See Cunha M.S., "A questão jurídica na crise dinástica", História de Portugal: no Alvorecer da Modernidade (1997) 465, 466. 
analysis being the marriage of João III with Catherine of Austria and that of Charles v with Isabella of Portugal. Third, analysis of sixteenth-century diplomatic correspondence discloses that while the Portuguese ambassadors maintained a cordial relationship with the English queen, the Spanish ambassadors to England were passionate and outspoken regarding the defence of the Catholic faith, often juxtaposing the religious and the political affairs in their diplomatic assignments which led to accusations of involvement in plots against the English queen. ${ }^{3}$ Despite the clear-cut difference between the Portuguese and the Spanish diplomatic policies, Elizabeth might have perceived Portugal as a Catholic power aligned with Spain with an anti-Protestant foreign policy.

The religious asymmetries that distanced Portugal and England from the Henrician schism onwards became secondary, however, compared to the mutual benefits provided by the commercial ties between Protestant England and Catholic Portugal, ${ }^{4}$ especially considering the wealth generated by the overseas expansion and the campaign of the sea explorations. Nonetheless, serious conflicts arose when England, under Elizabeth's rule, decided to systematically plunder Portuguese ships and traffic in the Portuguese territories in Northern Africa. Portugal regarded the English conduct as unfriendly and unacceptable, particularly in the context of the existing alliance, and dispatched several ambassadors to the Elizabethan court, in protest against English privateering. Between 1559 and 1564, Portugal sent three ambassadors to the Elizabethan court, on diplomatic missions: João Pereira Dantas, in 1559; Manoel d'Araújo, from 156o to 1561; João Pereira Dantas again, whose friendship with Elizabeth was used as leverage and made Portugal reassign him to England, where he stayed from 1562 to 1563; and Ayres Cardoso, in 1564. Therefore, within a period of six years, Portugal carried out four diplomatic missions to England, almost in every way resembling a permanent-resident diplomatic assignment, only with greater costs. In contrast, Elizabeth did not send a single English envoy to Lisbon, that is, not until Dr. Thomas Wilson, in 1567.

3 Some instances that confirm the friendly relationship between Elizabeth I and the Portuguese ambassadors to her court may be found in SP $70 / 58$, fol. $5^{2}$ (Letter from João Pereira Dantas to the English Queen), SPF Elizabeth 15:721 (Letter from Elizabeth I to Philip II - I of Portugal about the Portuguese ambassador António de Castilho's approved character for prudence and disposition to preserve peace and amity between princes). On the contrary, the Spanish ambassadors Álvaro de la Quadra, Guerau De Spes and Bernardino de Mendoza were expelled from England: the first in 1563, the second in 1571, and the third in 1584 .

4 Prestage E., "The Anglo-Portuguese Alliance", Transactions of the Royal Historical Society 17 (1934) 69-100; Oliveira S., "The Intolerable Business': Religion and Diplomacy under Elizabeth's Rule", SEDERI 26 (2016) 159-174. 
The surviving records referring to Elizabeth's instructions to Wilson are held at the British Library, in the Cotton Manuscripts, and include two documents: the first, a draft corrected by William Cecil, Elizabeth's Chief Advisor and Secretary of State, dated June 1567 , under the heading "Instructions for Wilson, Dr. of Law and Master of St. Catherine's, sent to the king of Portugal"; the second, is undated, although included in the section Portugallia 1567, with the following addition: "in Mr. Winter's cause". ${ }^{6}$ Thomas Wilson's account of his mission to the Portuguese court is recorded in a letter addressed to Cecil, on 12 October 1567 . The manuscript, in Latin, is also part of the Cotton Manuscripts. ${ }^{7}$

Bearing in mind that Wilson's letter has not received a detailed analysis and that the early modern studies of Anglo-Iberian foreign policies tend to focus almost exclusively on England and Spain, ${ }^{8}$ I propose to examine this mission to Lisbon by focusing on Wilson's narrative of events. ${ }^{9}$

For years, Portugal and England had exchanged arguments regarding the trade activities in Northern Africa, especially in Mina (the modern Elmina, in

5 BL Ms. Cotton Nero B1, fols. 125-126.

6 Ibidem, fols. 127-128.

7 Ibidem, fols. $135^{-136 .}$

8 Morales O.R., Review of O'Connor T., Irish Voices from the Spanish Inquisition: Migrants, Converts and Brokers in Early Modern Iberia, trans. M.J. Sánchez-de-Nieva SEDERI 27 (2017) 269-272, here 270.

$9 \quad$ My approach is greatly indebted to Visconde de Santarém's translation from the original Latin into Portuguese. Manuel Francisco de Barros e Sousa de Mesquita de Macedo Leitão e Carvalhosa, 2nd Viscount of Santarém, was born in Lisbon, in 1791, and died in Paris, in 1856. Historian, state archivist (Guarda-Mor) of the Portuguese National Archives (Torre do Tombo), diplomat, Minister of the Interior and of Marine and Overseas Territories, Santarém became one of the most prolific authors of his time, with significant contributions in the fields of Political and Diplomatic History, Geography and Cartography, Historiography, among others. For a more detailed approach to Santarém's biography and work, see Protásio D.E., $2^{\circ}$ Visconde de Santarém (1791-1856): Uma Biografia Intelectual e Política (Lisbon: 2018). Santarém's comprehensive study on the Portuguese diplomatic relations resulted in a nineteen-volume work, entitled Quadro elementar das relações políticas e diplomáticas de Portugal com as diversas potências do mundo desde o princípio da monarquia portuguesa até aos nossos dias (Lisbon: 1842-1876), published with the collaboration of other prominent scholars from the Portuguese Royal Academy of Sciences. No other work of similar wide-ranging scope and attention to detail has been published so far.

10 For the purpose of the present analysis, the societal and cultural phenomena associated with expansionism will not be considered. The native inhabitants of Mina would be 
Ghana). About fifty years after the beginning of the exploration of the West African coast, the Portuguese finally arrived at Mina, probably between 1471 and $1472,{ }^{11}$ as attested in several nautical charts, namely those included in the Cornaro Atlas, c. $1489 .{ }^{12}$ For example, chart 32 displays an image that represents the construction of the Castle of Mina, with a note specifying that the castle belonged to the King of Portugal. The castle would be named S. Jorge da Mina, in honour of the patron saint of Portugal, and its construction was completed in 1486, under the orders of Diogo de Azambuja. ${ }^{13}$ This cartography demonstrates the right of the Portuguese kingdom over the territories that would become the centre of the dispute between Portugal and England. As cartography evolved and improved both in technical and scientific accuracy, it also began to include the identifying symbols of the realms that dominated a given territory. ${ }^{14}$ In the context of the early modern sea explorations, this is an element of geopolitical significance, in the sense that the need of pointing out the rightful claim to a certain region with the symbol of the crown of the conquering kingdom, a 'sign of right', became apparent, as Manuel Francisco de Barros e Sousa, Visconde de Santarém observes:

From the end of the fifteenth century on, cosmographers began to indicate the sovereignty of the different territories with the Coat of Arms of the Kingdoms that dominated them [...]. The study of these indications shows that these 'signs of right' were not the result of their authors' whim, but on the contrary, the authors of these charts were scrupulous in including this important information. ${ }^{15}$

dominated - not conquered - by the Portuguese. It should be made clear that the use of terms that in contemporary times are considered 'imperialist' or 'colonialist' do not reflect the author's perspective.

11 Hair P.E.H., The Founding of the Castelo de São Jorge da Mina: An Analysis of Sources (Wisconsin: 1994).

12 Cornaro Atlas. BL Egerton Ms.73.

13 Newitt M. (ed.), The Portuguese in West Africa: 1415-1670: A Documentary History (New York: 2010) 9o-96.

14 Bagrow L., History of Cartography, rev. R.A. Skelton (New Brunswick - London: 1985) 105.

15 My translation from the original: 'Desde os finais do século Xv principiaram os Cosmographos a indicar a soberania dos differentes paizes que marcavam nas suas Cartas pelas Armas e Pavilhões nacionaes dos Principes que os dominavam [...] O estudo d'estes monumentos mostra que n'estes signaes de direito, longe de haver o menor capricho do desenhador, antes pelo contrario, os auctores de taes Cartas punham n'isto o maior escrúpulo'. Demonstração dos Direitos que tem a Coroa de Portugal sobre os Territórios situados na Costa Occidental D'Africa (Lisboa: 1855) 6. 
Portugal claimed the right over the territories, the sea and the commercial routes added to the kingdom by the sea explorations. However, numerous English adventurers and merchants were covertly involved in taking part of the riches that the Portuguese considered only they were entitled to, and they did so with Elizabeth's agreement. João Pereira Dantas's mission to England in 1562 was to complain against the English merchants that continuously infringed Portuguese commercial rights under the queen's approval:

The Crown of Portugal will never consent to share with others the sea explorations and conquest which have been so dearly purchased [...]. The Portuguese Kingdom has (for a long time now) absolute superiority over the whole of Ethiopia and the right to make such regulations with respect to it as may seem most to his advantage [...]. Apologises for the expression 'disguises by means of sophisticated arguments, ${ }^{16}$ in his former answer, and assures her of the goodwill of his King. ${ }^{17}$

In such an environment, diplomats worked to achieve some sort of compromise. Words had to be carefully chosen. On the one hand, João Pereira Dantas firmly advocates Portugal's complete supremacy over the territories in Northern Africa, while, on the other hand, he apologises for the expression that entailed Elizabeth's disguised attitude. The Portuguese ambassador addresses the English ambiguity in the negotiations ('deguisements par arguments sophisticques') and Portugal's acknowledgment of it, but he does so by resorting to ambiguity, as well. As a result of his apologetic tone, he encourages discussions to continue.

Ambiguity is essential to diplomatic activity. As Nathalie Revière de Carles suggests, the challenge embedded in every diplomatic mission is to put the rhetoric of ambiguity at the service of peace and agreement:

Diplomatic ambiguation [...] emerges as a means to generate appeasement whether on the domestic or the international level. Appeasement and peacemaking do not only rely on words or silence but on the conscious use of a material and commercial soft power. ${ }^{18}$

16 My translation from the original: 'deguisements par arguments sophisticques'.

17 MS Secretaries of State, SPF 70/38/146. An overview of the Portuguese ambassador's address to the English queen on 19 June 1562.

18 Carles N.R. (ed.), Early Modern Diplomacy, Theatre and Soft Power: The Making of Peace (London: 2016) 10. 
Portugal and England had benefited from a long-established alliance; despite going through a difficult period, both nations were still allies. Therefore, the ambassadors' negotiating skills became of the greatest importance within this context of apparent peace. Carles observes how early modern diplomacy was deeply associated with a consensus christianus and ultimately with the prospect of maintaining the peace among monarchs and diplomatic figures of all Christian faiths. ${ }^{19}$ However, in face of the English piracy and privateering activities, ${ }^{20}$ some Portuguese ambassadors found it difficult to uphold a peaceful or compliant conduct. For instance, the Portuguese ambassador Francisco Pereira wrote to the Portuguese Public Treasury overseer, arguing that the Portuguese would be better served by 'showing their teeth' to the English. ${ }^{21}$ Clearly, the ambassador was suggesting that the Portuguese crown should act more aggressively towards the English. Nevertheless, instead of presenting a blunt accusation regarding the queen's covert support of her subjects' privateering enterprise, the Portuguese ambassador focuses on the Portuguese attitude towards the English, while the representation of the queen's character is subtly implied.

\section{$2 \quad$ Wilson's Diplomatic Mission}

According to G.H. Mair, Thomas Wilson's career 'presents him as a man closely in touch with the three greatest forces in the England of his time - the Renaissance, the Reformation, and the revival of the State under the Tudors.' ${ }^{22}$ He was the author of the Arte of Logique (1551), Arte of Rhetorique (1553), and A Discourse upon Usury (1572), in addition to his English translation of Three Orations of Demosthenes (1570). He was also Master of St Katherine's Hospital in the Tower of London, Advocate of the Court of Arches, Master of Requests, and a diplomat. ${ }^{23}$ Wilson was, therefore, a humanist and a statesman, celebrated,

\footnotetext{
19 Ibidem 2.

20 English privateering caused great concerns within the merchants' community as well, since it 'interrupted a vigorous trade, that employed and enriched thousands of merchants, mariners, artisans, and clothworkers'. Eldred, J., "The Just will Pay for the Sinners': English Merchants, the Trade with Spain, and Elizabethan Foreign Policy, 1563-1585", Journal for Early Modern Cultural Studies 10 (2010) 5-28, here 6. The Cotton Collection contains several documents that confirm the merchants' anxieties concerning the trade interruption between Portugal and England. BL Ms. Cotton Nero B1, fols. 146-152.

21 My translation from the original: 'mostrar os dentes'. ANTT Corpo Cronológico 1/103/61.

22 Mair G.H., "Introduction", Wilson's Arte of Rhetorique 1560 (London - Edinburgh - New York - Toronto - Melbourne: 1909) xiv.

23 Tawney R.H., "Introduction", in Wilson T., A Discourse upon Usury (London: 1925) 2.
} 
as Anthony Wood noted, '1) for quick dispatch and industry, 2) for constant diligence, and 3) for a large and strong memory'. ${ }^{24}$

By their very nature, Thomas Wilson's attributes must have earned him the Privy Council's trust and respect. Moreover, one other significant factor emerges in the context of Wilson's diplomatic assignment to Lisbon. As mentioned in the 'Instructions', Wilson's purpose was to defend 'Mr. Winter's cause, ${ }^{\prime 25}$ and, coincidentally, the naval officer and Admiral William Winter was also Wilson's brother-in-law. Thomas Wilson had married Winter's sister, Agnes Brooke, sometime after 1560, and would now use his attributes and skills in the service of the English crown, as well as of his own entrepreneurial family. ${ }^{26}$ Selecting Wilson emerges, therefore, as a wise governmental decision, in line with the epigraph of this chapter.

Santarém clarifies the incident involving Wilson's brothers-in-law, Captain William Winter and his brother George Winter:

In [...] 1565, the Portuguese warships attacked and sent to the bottom, near the Rio dos Cestos [today's Nuon or Nipoué river, in Liberian territory], a ship of the Winter Brothers, with 24 crew members and a load valued at $£_{7}, 600$ pounds. As the people who were interested in this business were of great influence, it caused a great irritation, especially in the merchants of the coast cities of England, who complained to the Queen. ${ }^{27}$

The Winters' episode had become a source of indignation for the English community of merchants, and the queen acted in their defence. Wilson's task in the Portuguese court was to formally express the English queen's displeasure and make a firm protest against the Portuguese conduct at sea: she simply could not approve of Portugal's policy, which included sinking English ships, seizing their cargo and imprisoning their crews. The fact that English privateers had been

24 Wood A., Athenae Oxonienses: An Exact History of All the Writers and Bishops who Have Had Their Education in the University of Oxford. To which are Added the Fasti, Or Annals of the Said University, vol. 2 (London: 1815) 174.

25 BL Ms. Cotton Nero B1, fols. 127-128.

26 Derrick T.J., "Introduction", in Wilson T., Arte of Rhetorique (New York: 1982) xxxvi; Tawney, "Introduction" 6.

27 My translation from the original: 'No anno seguinte de 1565 os navios de guerra Portuguezes, atacárão e metterão no fundo perto do Rio dos Cestos um navio dos Irmãos Winter, com 24 pessoas de tripulação; e a carga avaliada em 7,6oo libras esterlinas. Como fossem os interessados neste negocio personagens de grande influencia, causou este facto uma grande irritação principalmente nos mercadores das cidades marítimas d'Inglaterra, que representarão á Rainha contra elle' (Santarém, Quadro Elementar, vol. 15 [1865] cxix, cxx). 
endangering both the Portuguese economy and the Anglo-Portuguese Alliance for decades was an irrelevant coincidence, a matter that the English emissary would have to avoid at all costs. In fact, the irony regarding Wilson's task was that all the previous Portuguese diplomatic missions to the Elizabethan court had envisioned the exact purposes of complaint and compensation, only the other way around. Therefore, Wilson's embassy involved considerable political and economic complexities, as well as disagreements.

Elizabeth further declares that England does not recognise the authority or jurisdiction of Portugal to judge or imprison English subjects, which was the case with several English held captive by the Portuguese in the Castle of Mina. ${ }^{28}$ Nonetheless, the Portuguese crown regarded this political measure to be legally justified, as Diogo Barbosa de Machado reports:

At the same time $[\ldots]$ news came $[\ldots]$ that the Queen, equally unfaithful to God, had resolved to break the peace and friendship [...] with this kingdom. As it happens, among the English who traded in Costa da Mina, a man called Winter, loathing the orders with which our King banned the navigation of foreigners, continued the trade in that port. To this insolence the Portuguese responded by seizing Winter's ships and their cargo. Seeing that he had been deprived of the wealth from his greed, Winter complained to the Queen, who, irritated against the Portuguese actions, granted him a Letter of Mark so that as a pirate he might be satisfied, repaying the Portuguese for the damage they had caused him. With this pardon, unworthy of a sovereign, Winter navigated in these seas, stealing all our merchant ships. ${ }^{29}$

28 BL Ms. Cotton Nero B1, fols. 125-126.

29 My translation from the original: 'Ao tempo, [...] lhe chegou a noticia [a D. Sebastião] de outro aggravo, com que a Rainha igualmente infiel a Deos, como ao nosso Principe se resolvera a romper a paz, e amifade, que observava com este Reyno. Succedeo, que entre os Inglezes, que comerciavaõ na Costa da Mina, hum chamado Vinter desprezando as ordens, com que o nosso Monarcha pohibira aquella navegação aos estrangeiros, se atraveo a continuar o commercio naquele porto, por cuja insolencia lhe tomaraõ os Portuguezes o navio com todas as fazendeas, que levava. Vendo se privado de tudo quanto tinha adquirido na sua cubiça, se queixou à Rainha, a qual irritada deste procedimento lhe concedeou Carta de marca para que como pirata se satisfizesse nas fazendas dos Portuguezes do damno, que deles recebera. Com este indulto indigno da soberanía de huma Princeza discorria Vinter por aquelles mares roubando a todas as nossas naos mercantes, que navegavaõ na segurança da paz, que esta Coroa tinha com todos os Principes da Europa' (Barbosa de Machado D., Memorias para a História de Portugal: Que Conprehendem O Governo del Rey D. Sebastião, vol. 2 (Lisbon: 1737) 734-735). 
If Machado's words are an accurate account of the Portuguese government spirits, then the Queen of England was construed as disloyal and untrue, both to God (as a Protestant monarch) and to the Anglo-Portuguese Alliance. Portugal was determined to preserve the monopoly over its territories, although the Portuguese ambassadors rejected the use of the term 'monopoly'. ${ }^{30}$ England, on the other hand, maintained an ambiguous policy, declaring the prohibition of the English trade in the territories under Portuguese rule, while simultaneously issuing Letters Patent as in the case of Captain William Winter. Wilson's mission was, therefore, challenging: he had to ask for financial compensation in favour of Winter's cause; but, if Winter had been plundering the Portuguese ships under the queen's indulgence, that would mean a double compensation for an activity that the Portuguese considered a crime. Moreover, Wilson's commission was also inauspicious: the English queen had broken her loyalty to a long-lasting ally, and each Portuguese ambassador sent to London had come back to Lisbon empty-handed. Should Elizabeth expect the Portuguese king to act differently towards her ambassador? Wilson may have associated the complexity and inauspiciousness of his diplomatic assignment with the great storm that he had endured at sea and the illness that followed. ${ }^{31}$

The English ambassador arrived in Lisbon on 5 October 1567 . He may well have taken a while to contemplate the bustle of the Lisbon port, significant in the overseas traffic system of the time, representing a market increasingly important to England, ${ }^{32}$ in the context of the political and religious revolts in the Netherlands (which in turn affected the English trade in Antwerp) and the Spanish embargo that had started in 1563 due to English privateering and the deteriorating Anglo-Netherlands relations. ${ }^{33}$ The seaport of Lisbon had achieved an important standing, especially considering geo-political, economic or even logistical contexts as a result of the overseas expansion. The merchants' networks, 'sustained by capital transfers, by the placement of agents in trade markets', specialised labour force, shipbuilding activities, the connections to other international (and national ports) introduced different

\footnotetext{
30 As confirmed in João Pereira Dantas's speech to the English queen, in which he refers that he is glad that the word 'monopoly' is not associated with his king (SPF 7o/38, fol. 146).

31 The following details of Wilson's mission in Lisbon are taken from his letter to Cecil. BL Ms. Cotton Nero B1, fols. 135-136; Santarém, Quadro Elementar vol. 15, 171-176.

32 Croft P., "English Mariners trading to Spain and Portugal, 1558-1625", Mariner's Mirror 69 (1983) 251-266.

33 Wernham R.B., Before the Armada: The Growth of English Foreign Policy 1485-1588 (London: 1966) 282 .
} 
commercial and social dynamics in various levels and scales of influence. ${ }^{34}$ Additionally, Lisbon's market was linked to a solid, 'trans-imperial networks of merchants', who shared intelligence across well-established networks about the 'presence of non-Portuguese ships on the African coast'.35

Unfortunately, instead of establishing some sort of communication with the English community living in Lisbon straight away, Wilson was hospitalised. ${ }^{36}$ There, he was visited by Ayres Cardoso, the Portuguese ambassador he had formerly met in London, who welcomed him. The diplomats spoke in French and, on behalf of the Portuguese King, D. Sebastião, Cardoso requested the hospital to offer the best services to the English envoy and a physician was sent to him. Wilson mentions that the doctor was so diligent, that he recovered his 'strengths and wits' right away.

Wilson further informs that after the doctor's call, he had another visit, this time from an officer of the Inquisition. Both men talked initially in Latin, although Wilson mentions that they switched into French, as the official's Latin was poor, and Wilson did not speak Portuguese. Despite the communication difficulties, the ecclesiastical representative asked Wilson if he was in possession of forbidden books, and Wilson replied that, as a scholar, he had only brought Law books, once they were a useful resource to carry out the mission entrusted by the English queen. It was common procedure for the Familiares, or the Inquisition agents, to come and visit English foreigners, looking for

34 Polónia A., "European Seaports in the Early Modern Age: Concepts, Methodology and Models of Analysis", Cahiers de la Méditerranée 8o (2010) 17-39.

35 Ebert C., "European Competition and Cooperation in Pre-Modern Globalization: 'Portuguese' West and Central Africa, 1500-160o', African Economic History 36 (2008) $53-78$.

36 In his letter, Wilson states that he had to be admitted into a hospital as soon as he arrived. It is impossible to tell which hospital it was. In the sixteenth century, Lisbon had about 76 hospitals, an average of 5 beds per hospital, and 100,ooo inhabitants, which meant a hospital bed for each 263 inhabitants. Such low ratio may explain why some hospitals were turned into care homes, specially intended for lodging people passing through. If that was Wilson's choice, then perhaps he might have stayed in Albergaria dos Palmeiros, close to Terreiro do Paço, where he had come ashore. Another possibility might have been Albergaria de Payo Delgado, one of the most important hospitals in Renaissance Lisbon, close to Palácio dos Estaus, in Rossio, a palace used by foreign embassies until 1584, when it was turned into the Inquisition quarters under the reign of Philip II of Spain, I of Portugal (Brearley M., Hugo Gurgeny: Prisoner of the Lisbon Inquisition (London: 1947) 19). If, on the other hand, Wilson decided to admit himself into a conventional hospital, then, Hospital Santa Maria dos Mártires, close to Terreiro do Paço, or Hospital Real de Todos os Santos, close to Rossio, are also to be considered, for the same reasons. For more on sixteenth-century Lisbon hospitals see Correia F.S., "Os Velhos Hospitais da Lisboa Antiga", Revista Municipal 2, 10 (Lisbon: 1941) 3-13. 
Bibles and prayer books in luggage and ship cargoes. ${ }^{37}$ In fact, Games observes 'the chilly effect' the Inquisition had on English merchants' businesses and even on national pride..$^{38}$ So, the Inquisitorial officer's visit to Wilson would have been expected, and the envoy's reply might have also been prepared, in the sense that he strategically mentioned the Queen of England and the King of Portugal to display his rank in the political sphere and to discourage further enquiries. Be that as it may, 'the man of the Inquisition' did not leave Wilson without a message, warning: 'I caution you to conduct yourself piously and to not arise amongst us any schism. ${ }^{39}$ Religious asymmetries distanced the two kingdoms even further, while simultaneously emphasised the role of diplomacy in the establishment of a common ground of understanding, a bridge between two worlds.

Among the foreign communities in sixteenth-century Portugal, the English were the most prominent and, according to Brearley, 'probably the most numerous. ${ }^{40}$ Nonetheless, Games observes that the English community in Lisbon was small (only twelve merchants in 1610), although she adds that this was 'the most prominent of the foreign merchant communities in Portugal'.41 Unlike the records that were preserved through the centuries on the English community living in Oporto, the Lisbon archives do not offer much information on the English community living in Lisbon in the sixteenth century, most probably because it was lost in 1755 Lisbon earthquake. However, it is possible to collect some evidence about this community in scattered documents. With the Reformation, many Englishmen arriving in Lisbon and Oporto held opinions and doctrines which were perceived as a social and religious menace by the Portuguese Catholics. Religion and politics were intertwined and inseparable. Therefore, the ever-present schismatic question became apparent in the words of the Portuguese Inquisition officials. The National Archives in Torre do Tombo hold numerous documents recording how Englishmen were sentenced by the Portuguese Holy Office of the Inquisition. One such instance is the trial of Richard Heron and Peter Starne, in the same year as Wilson's visit. ${ }^{42}$ The 20 -folio record refers to the accusation of 50-year-old Heron, a

\footnotetext{
37 Brearley, Hugo Gurgeny 18.

38 Games A., The Web of Empire: English Cosmopolitans in an Age of Expansion, 1560-1660 (Oxford: 2008) 100.

39 In the original: 'ego moneo tē, ut pie te geras, et schisma nullum inter nos excites'. BL Ms. Cotton Nero B1, fol. 135; Santarém, Quadro Elementar vol. 15, 172.

40 Brearley, Hugo Gurgeny 23.

41 Games, The Web of Empire 100.

42 ANTT Tribunal do Santo Ofício IL/28/01672.
} 
Welsh merchant, and 45 year-old Starne, an English sailor. Both men were accused of Lutheranism. The role of a Protestant diplomat in a Catholic foreign court embodied, therefore, the absolute need for prudent and expert negotiating skills, if a common ground of understanding were to be established.

Wilson's reply to the Inquisitor's message of warning was simply to state that his affairs in Portugal were not religious but rather the business of the two kingdoms. He notes that this answer particularly pleased the officer; then, he resumes to describe his audience with the Portuguese king and his advisors, on 9th of October: he delivered a speech at the High Chambers, stated his demands and exchanged some laudatory words with the King (D. Sebastião spoke in Portuguese and Wilson in Italian). Then, Wilson describes his meeting with the queen dowager, Catherine of Austria, D. Sebastião's grandmother. ${ }^{43}$ She was old, large, with a majestic posture, sitting on the throne, surrounded by court ladies. The conversation with the queen was held in Spanish, and numerous compliments were shared. Ultimately, Wilson observes that the Portuguese sovereigns were very friendly and pleasant.

After the audience, he was accompanied by a large entourage of Englishmen, one hundred on foot and six on horseback, to the house of Botolph Holder, a wealthy English merchant with a great reputation within the Portuguese court. This account emphasises the success and vitality of the English community in sixteenth-century Lisbon and how Wilson's mission broadened the network of intelligence that would be vital to England's approach to Portugal's strategies. In fact, according to the Spanish ambassador Bernardino de Mendoza, Botolph Holder would become 'hand in glove' with Wilson from this assignment to Lisbon onwards. In a letter to Philip II, Mendoza observes how Holder sent information to Wilson on everything that occurred in Portugal, for the queen's knowledge. ${ }^{44}$ If this sort of collaboration favoured England politically, it also worked to the advantage of the English community of merchants established in Lisbon, since the peaceful resolution of the Anglo-Portuguese commercial disagreements would advance their prospects of trade. Holder's letter to William Cecil, on 14 May 1568, confirms not only that he was by then at the queen's service, undoubtedly following Wilson's recommendation, but also that he was supplying detailed intelligence on the number of Portuguese ships departing from Lisbon, the situation of the English sailors that were captive at Terceira Island, in the Azores archipelago, and on the great loss resulting

43 Catherine of Austria, from the House of Habsburg, was the regent of Portugal from 1557 to 1562 .

44 Hume M.A.S. (ed.), Calendar of Letters and State Papers Relating to English Affairs Preserved Principally in the Archives of Simancas, vol. 3 (Cambridge - New York: 1896) 183. 
from the currency devaluation, which seriously affected the reputation of the English living in Lisbon. ${ }^{45}$

In this context, we should also consider another network of exchange: the one between the English community in Lisbon and the religious institutions. As a result of the 1535 Oath of Supremacy, which required all English subjects to pay allegiance to their monarch as the Supreme Head of the Church of England, numerous English Roman Catholics were driven out of their country and settled in Lisbon. Most of the English and Irish priests took refuge in the Church of São Roque, a Jesuit church since 1553. Two such cases were those of John Rolles and Sir Francis Tregian, who obtained board and pension at Jesuit and Franciscan monasteries in Lisbon. Sir Tregian's tomb in São Roque, commissioned by the local English Catholic community seventeen years after his death in 1608 , stands out as a commemorative symbol of the resistance to the Elizabethan establishment of the Church of England and to the fostering of English Catholics in Portugal. Additionally, there was no English foundation in Lisbon except the Brigittine nuns' sanctuary. The nuns had left England in the course of the dissolution of the convents and monasteries and arrived in Portugal in 1594. They finally settled in 1599 in Rua das Quelhas, founding the sanctuary. It is still possible to perceive the sixteenth-century Anglo-Portuguese network of exchange in today's toponomy of the city of Lisbon, namely Travessa dos Inglesinhos, in the ancient quarter of Bairro Alto. The name of the street echoes the founding of the English College of Saints Peter and Paul, a project that started in 1568, under 'the design of establishing a College at Lisbon for Secular Priests who should serve on the English Mission.' ${ }^{46}$ During Wilson's stay in Lisbon, he would have become familiar as this initiative was being designed, funds assembled, and assistance provided to an increasing English Catholic community living in Lisbon.

Wilson was also received by Cardinal D. Henrique, D. Sebastião's great-uncle and regent of Portugal. ${ }^{47}$ Despite the Cardinal's very pleasing words and promise of an expeditious dispatch of business, Wilson complains that eleven days went by without an official reply from the Portuguese court. As a consequence, he visited the Portuguese Royal Secretary, who received him and very kindly promised to take care of the matter. They also talked a great deal about John Hawkins's navigation, and Wilson informed Cecil that the Portuguese had 6 ships, 4 galleys and 4 triremes ready to prevent such navigation, since it was

45 Crosby A.J. (ed.), Calendar of State Papers Foreign: Elizabeth, vol. 8 (London: 1871) 448-457.

46 Croft W., Historical Account of Lisbon College (Barnet: 1902) 2.

47 D. Sebastião was then 13 years old and took office as King of Portugal in January of the following year. 
believed that Hawkins's project was to seize the Castle of Mina and to devastate those parts.

By this time, Wilson had already interacted with the three people responsible for the Portuguese policy of foreign affairs and diplomacy during the reign of D. Sebastião. In 1557, when D. Sebastião inherited the throne, he was just a three-year-old child. It was his grandmother, Catherine of Austria, who assumed the regency, maintaining the foreign affairs policy of her husband, King D. João III, that is, one of close collaboration, even at times subordination, to Philip II's goals and Spain's interests. This line of government generated many internal conflicts and precipitated the beginning of Cardinal D. Henrique's regency (from 1562 to 1568 ), who assumed a frequently distant, silent, and always cautious alignment regarding Portugal's position in the geo-political framework of the times. Although he was not openly hostile to his nephew in Castile, Cardinal D. Henrique clearly demonstrated that he was not going to maintain Catherine of Austria's policy of preferential treatment and partisanship with Spain. He started to enforce a foreign policy which favoured Portuguese interests, carefully measuring, scrutinising and adjusting each negotiation in favour of the national benefit. ${ }^{48}$ Although D. Sebastião only assumed the government of his reign a few months after Wilson's departure, by the time the English envoy was staying in Lisbon, D. Sebastião was already taking an active part in many political decisions, especially those which concerned his uncle, Philip II. The King of Spain tried to maintain his interference in the Portuguese affairs, but now he found a greater resistance: both from the Cardinal D. Henrique and from D. Sebastião. ${ }^{49}$ In January 1568, when D. Sebastião became King of Portugal, he distanced his foreign policy from that of his Castilian uncle's even further, seeking a trade agreement with England, dealing with the multiple consequences of an Atlantic full of English and French privateers and pirates, pursuing a balanced political relationship between the various kingdoms and republics (Catholic or otherwise, precisely in line with the consensus christianus mentioned by Carles), and working for a prominent position of Portugal in Christendom, especially within the context of the rising threat of the Ottoman Empire. ${ }^{50}$

48 Magalhães J.R., "D. Sebastião", in Mattoso J. (ed.), História de Portugal: no Alvorecer da Modernidade (Lisbon: 1997) 453, 46o.

49 This resistance to Philip II's interference became even more overt when the King of Spain decided the rightful suitor to marry the Portuguese king. That decision was not approved by D. Sebastião, who openly defied his uncle. Cruz M.A.L., D. Sebastião (2006) 108; Baños-Garcia A.V., D. Sebastião: Rei de Portugal (2006) 96-10o.

50 Amorim P.A.S., A Política externa de D. Sebastião: Portugal na Cristandade às vésperas de Alcácer-Quibir MA thesis (University of Lisbon: 2019) 5. 
In his letter, Wilson mentions the English merchants in Lisbon, namely those who were treated very harshly and put in prison, despite being innocent. Since he does not mention the reason behind such behaviour by the Portuguese authorities, we may speculate that the Inquisition and the matters of faith might have been involved. Games mentions that 'insufficient observance of Catholic rituals by a single mariner might condemn an entire crew to interrogation and punishment' and that merchants complained about this sort of 'collective retribution'.51 Although this account refers to the English community in Lisbon some decades after Wilson's assignment (and after the union of the crowns of Portugal and Spain, in 1580), we may presume that differences would not have been substantial and that the English merchants lived as if in a city within the city of Lisbon to protect themselves. ${ }^{52}$

Wilson also reports an incident that had occurred in July: a ship loaded with goods, carrying no weapons and with a crew of ten sailors, had left Lisbon for San Lúcar, in Spain. Immediately after its departure, a Portuguese fleet apprehended it near the Berlengas islands, under the pretext that it was, in fact, a pirate vessel and the crew was, consequently, stripped of everything and imprisoned. Wilson adds, however, that he does not excuse them, because they were regarded as pirates. Using J. Eldred's analysis of what he calls the two distinctive groups of English merchants (that, in turn, embodied opposing perspectives about English foreign policy), we presume that here Wilson is referring to the 'martial maritime faction', whose fierce undertakings at sea promoted private gain instead of the public good and long-term interests and gains of the commonwealth championed by the peaceful trade defended by the other group, 'the mercantile merchants.' ${ }^{33}$ Wilson's mission was also to recognise how the Anglo-Portuguese Alliance could be maintained in terms of commerce, despite the Spanish embargo on ships sailing from English ports and the continuous English violence at sea that damaged peaceful trade negotiations. England found in the ports of Portugal and in those of Portuguese islands alternative markets. ${ }^{54}$ It is my understanding that although the English government perceived the Iberian nations as kingdoms with much in common, the differences between Portugal and Spain were also apparent and Wilson makes reference to the English martial maritime men that endangered the peaceful negotiations with Portugal.

51 Games, The Web of Empire 100.

52 Games refers to "a cautious insularity" (Ibidem 102).

53 Eldred, "The Just will pay for the Sinners" $5^{-9}$.

54 Croft P., "Trading with the Enemy 1585-1604", The Historical Journal 32, 2 (1989) 281-282. 
The English envoy continues to refer to other English seamen (about thirty of them) confined in the horrible prison of the Castle of Mina, despite being innocent. Wilson's account confirms that the Portuguese had increased and reinforced their position of guardianship against English voyages. The unsatisfactory results for compensation of the Portuguese diplomatic missions to the Elizabethan court had undoubtedly led to this state of affairs, even though Wilson assures Cecil that the Portuguese detest war ('Lusitanus a bella abhorrore'), ${ }^{55}$ and do not want to break treaties. The uneasy relationship between the two kingdoms included at this stage mutual reprisals and armed hostilities, emphasising the importance both of the English and the Portuguese diplomatic missions. Despite being allies, the two kingdoms were on the verge of ending their friendly Alliance.

Bearing in mind that the Iberian kingdoms had such strong familial, political, economic and religious ties, Wilson's mission must have included the surveillance of Spanish activities and indeed he informs Cecil that the Spanish ambassador, resident in the Portuguese court, visited him regularly, treated him with the greatest courtesy and shared with him rumours about French naval activities. Wilson's stay in Lisbon provided him with numerous opportunities to expand his political intelligence, not only regarding the Anglo-Portuguese affairs, but also at a wider level of international concerns.

\section{3}

\section{The Aftermath of Wilson's Mission to Lisbon}

Given what Elizabeth hoped to achieve, Wilson's diplomatic mission was partly unsuccessful: the Portuguese king did not accept England's demands for Captain Winter's compensation. But not all of Wilson's endeavours were in vain.

Following the English queen's instructions, Wilson resorted to the authority of a public notary, who registered the envoy's protest in his final audience with the Portuguese king, on 30 October $1567 .^{56}$ Religion, politics and economy are evoked by the English diplomat to fulfil a purpose, that of his mission and, underlying it, the preservation of the Anglo-Portuguese Alliance.

Notwithstanding Portugal's irreversible position regarding both the English commercial activities on the African coast and Winter's claim for compensation, Wilson's mission to Lisbon succeeded in the release of the Englishmen held captive in the Castle of Mina, as confirmed in a letter from the Portuguese

55 BL Ms. Cotton Nero B1, fol. 136r.

56 Ibidem, fols. 131, 132. 
king to the English queen. ${ }^{57}$ Furthermore, Wilson's diplomatic mission also meant the establishment of a wider net of important and influential connections, as well as the reinforcement of the liaisons within the English community living in Lisbon, as was the case with Botolph Holder.

One should also consider the fact that Wilson had become the first envoy to be sent to Lisbon by Queen Elizabeth, which established a predisposition to keep the negotiations concerning the protection of trade and naval traffic between the two kingdoms, a central subject within the context of the Anglo-Portuguese relations. The fact that the only envoy sent to Portugal from England during this period was sent to claim the rights of English merchants is significant. Ambassadors on both sides were working laboriously to avoid a commercial embargo, such as the one with Spain, although Portugal was by now reaching breaking point.

Following Wilson's mission, Portugal decided to send another envoy to London, the fourth since the beginning of Elizabeth's reign. That also confirms Wilson's successful and effective performance in Lisbon: Portugal was still willing to reach an agreement. In April 1568, the Portuguese ambassador Manoel d'Alvares requested the queen's prohibition of all the English trade in the coast of Guinea, that those of her subjects disobeying her orders be punished with death, and a restitution of 6o,ooo ducats to compensate the Portuguese kingdom for the English pirates' activities. ${ }^{58}$ In the following month, Elizabeth replied:

[...] the Queen does not admit of the King's right to make laws binding on her subjects, since his are excluded from trading in no part of her territory [...] she will warn her subjects not to traffic in those parts of Ethiopia owning the King's rule or paying tribute to him [...] it is unreasonable to hold her liable for the faults of her subjects in which she was in no way participant. ${ }^{59}$

Elizabeth maintained an ambiguous political strategy, although the discourse reveals an increasingly clearer response to Portugal's demands. We must assume that, at this stage, Wilson would be completing the above-mentioned English translation of Three Orations of Demosthenes. According to Blanshard and Sowerby, Wilson's work politicises classical translation and rearranges the role of Demosthenes from orator into statesman. Wilson is therefore emphasising the importance of experienced statesmanship (such as diplomacy), while

\footnotetext{
57 Ibidem, fols. 133, 134 .

58 Ibidem, fols. 138-140.

59 Crosby, Calendar of State Papers Foreign vol. 8, 457-472.
} 
simultaneously advocating against the English queen's foreign policy and in favour of a reinforced action against Spain. ${ }^{60}$ Regarding the other Iberian nation, and due to Wilson's mission to Portugal, 'he continued to be consulted as a recognised specialist in Portuguese affairs and questions of trade. ${ }^{61} \mathrm{He}$ exchanged correspondence with the English trade consul and representative of the English community in Lisbon, John Lee, who was kept in office for twelve years. ${ }^{62}$ When the Portuguese ambassador Manoel d'Alvares was involved in an incident that could endanger the delicate balance of the Anglo-Portuguese affairs, Thomas Wilson emerged on the scene. ${ }^{63}$ Ultimately, diplomacy, mercantile and religious networks of knowledge and intelligence exchange became crucial in the decisions of the Portuguese king and the English queen regarding their kingdoms' foreign policy.

Wilson's recently-added skills became considerably more important when England and Portugal ceased their friendly political and economic alliance, in 1569. For a period of seven years, Anglo-Portuguese affairs, as well as their national treasuries, suffered deeply on account of the differences confronting both nations. ${ }^{64}$ Wilson worked alongside the Portuguese resident ambassador Francisco Giraldes, whose mission in London from 1571 to 1578 intended to reinstate Anglo-Portuguese commercial trade. This was a period for energetic diplomatic agency, confirming that the role of the ambassador had become essential on the political stage, as the diplomatic skills and services had become indispensable in (re)establishing and maintaining the peace.

Thomas Wilson, died in May 1581, only a month after the legal establishment of the Iberian Union and Philip II's recognition as King Philip I of Portugal, on 16 April 1581. Portugal ceased its diplomatic representation in England from then onwards, a practice that was only resumed in 1641 , after the Restoration of the Portuguese monarchy.

6o Blanshard A.J.L. - Sowerby T.A., “Thomas Wilson's Demosthenes and the Politics of Tudor Translation'", International Journal of the Classical Tradition 12, 1 (2005) 46-80.

61 Tawney, "Introduction" 4.

62 Games A., The Web of Empire 10o. See also the letter from Hugh Lee to Thomas Wilson, 3 June 1610. sP $89 / 3 / 140^{v}$.

63 Manoel d'Alvares's house in Hoxton was invaded by the agents of the Bishop of London and the Portuguese envoy was accused of covering Englishmen attending the Catholic mass. Thomas Wilson arrived on the scene, as reported by the Spanish ambassador, Guzman da Silva. Hume M.A.S. (ed.), Calendar of Letters and State Papers Relating to English Affairs Preserved Principally in the Archives of Simancas, vol. 2 (Cambridge - New York: 1894) 8o-81.

64 The Cotton Manuscripts hold several records attesting to the merchants' concerns and complaints as a consequence of the Anglo-Portuguese commercial interregnum. See section Nero $\mathrm{B}$, fols. $162-168$. The original of the declaration of the merchants trading to Portugal is in SP12/83/37. 
As this chapter suggests, the theme of networks of exchange in the sixteenth century is inextricably entwined with diplomacy. This period witnessed a substantial expansion in diplomatic correspondence. It should be noted that the information network depended not only on diplomatic envoys and resident ambassadors in foreign courts, but also on numerous agents and intelligencers. This expanded network of correspondence would ultimately result in a vast exchange of intelligence, with enormous political and financial benefits.

This chapter's primary sources, the accounts regarding Thomas Wilson's assignment to Lisbon, those of the Portuguese ambassadors dispatched to the Elizabethan court, are mainly held at the British Library and the National Archives, in London. Unfortunately, the Portuguese diplomatic accounts are often overlooked as a resource in early modern studies. ${ }^{65}$ The difficult access to these records, along with the challenging interpretation of their contents, may explain why we rarely find any references to the Portuguese ambassadors' written accounts. Nonetheless, one expects that the contemporary interpretation of early modern times will expand, as more records of diplomatic correspondence are salvaged from the existing archives, such as some of the manuscripts cited in this chapter.

In this regard, the Portuguese National Archives hold several significant letters concerning the way in which the ambassadors gathered information and how they perceived the importance of their missions. In a letter to D. Sebastião, the Portuguese ambassador in Rome, Lourenço Pires de Távora, affirmed:

And those who acquire a reputation for being obedient should not only show it in observance and respect, but also in all external activities. And since ambassadors represent the names of their kings and are necessary so that their kings are remembered, it seems in a way that where they are missing, forgetting is easier. ${ }^{66}$

65 Even in the context of the Iberian Peninsula, as pointed out, early modern studies tend to focus almost exclusively on Spain. First, that may be due to the fact that the sixteenthcentury Portuguese correspondence is rare, either because it was lost in the 1755 Lisbon earthquake, or during the French invasion in 1807 , or because it remains forgotten in the private papers of the Portuguese ambassadors' families. A second reason may lie in the fact that the Portuguese diplomats often wrote between the lines, as an evidence of political caution. A third reason may be related to the fact that the surviving records of the Portuguese ambassadors in the Elizabethan court are scattered in several European archives, mostly remaining uncatalogued.

66 My translation from the original: 'E os que quiserem ser tidos em reputação de obedientes, não devem somente mostrá-lo na observância e acatamento, mas ainda em todas as obras exteriores. E como os embaixadores representam o nome dos seus Reis e são 
Pires de Távora reflects on how ambassadors contribute to the achievement of compromises, but the apology he puts forward goes beyond the practical question that, at first glance, seems to be the focus of his missive. In a way, Pires de Távora appeals to the Portuguese king, so that he regards his ambassadors, especially resident ambassadors, as visible signs of his authority, for 'they represent the name of their kings'. Underpinning this idea is the metaphor of 'exterior paintings', which symbolised the real, and royal, persona. For such an ambassador, the authority of the monarch did not depend only on the demonstration of 'observance and respect', that is, on the passive, intrinsic and required qualities in international political relations. At a broader level, the monarch's authority also depends on the active demonstration of authority in a given foreign court, on the agency of the resident ambassadors as the embodiment of such authority. They represented - as a process of mimesis in the artistic creation of the 'exterior paintings' - the real authority of their sovereigns and thus functioned as a constant evocation and reminder of the reality they reproduced. In the external political context, that would undoubtedly be of decisive importance.

Drawing on the epigraph of this chapter, governance and leadership presuppose, among other things, the wise use of ambassadors:

Alas, how should you govern any kingdom

That know not how to use ambassadors?

w. Shakespeare, Henry vi, Part 3 IV.3.35-36

These lines sum up, with the expressive virtuosity Shakespeare renders Richard Neville, Earl of Warwick, not merely the core of the play, but also the political shift of events within the context of the Wars of the Roses. The causal explanation is indeed pointed out: King Edward IV had discredited Warwick's diplomatic mission, depriving it of its content. The dramatic mimesis of the political stage evokes the correlation between the sovereigns' political status and the international signs that embody it, as the ambassadors, their representatives. To void the diplomats of the content of their representation means to void the very sovereign of his/her authority; contrarily, empowering ambassadors and reinforcing the importance of diplomatic missions amplifies the sovereign's influence and authority. Such seemed to be the case with the Portuguese ambassadors, with the English ambassadors and with their sovereigns, mentioned in this chapter.

["sejam" no original] umas pinturas necessárias para a lembrança, parece de certo modo que onde eles faltam é mais fácil o esquecimento' (ANTT Corpo Cronológico 1/105/50). 


\section{Bibliography}

\section{Primary Sources}

Arquivo Nacional da Torre do Tombo, Lisbon (= ANTT)

Corpo Cronológico $1 / 103 / 61 ; 1 / 105 / 50$

Tribunal do Santo Ofício IL/28/01672

Ascham R., The whole works of Roger Ascham, ed. Rev. Dr. Giles, 2 vols. (London: 1864). British Library, London (= BL)

Ms. Cotton Nero B1

Ms. Egerton 73

Crosby A.J. (ed.), Calendar of State Papers Foreign: Elizabeth, 23 vols. (London:1871).

Hume M.A.S. (ed.), Calendar of Letters and State Papers Relating to English Affairs Preserved Principally in the Archives of Simancas, vols. 2-3 (Cambridge - New York: 1894-1986).

The National Archives Kew, Public Record Office

State Papers (= SP) 12/83/37

State Papers $70 / 58 / 37$

State Papers $89 / 3 / 140^{v}$

State Papers Foreign (= SPF) 70/38/146

Shakespeare W., Henry VI Part III, ed. R. Martin (Oxford - New York: 2001).

Wilson T., Arte of Rhetorique ed. T.J. Derrick (New York: 1982).

Wilson T., Wilson's Arte of Rhetorique 156o, ed. G.H. Mair (London - Edinburgh - New York - Toronto - Melbourne: 1909).

Wilson T., A Discourse upon Usury, ed. R.H. Tawney (London: 1925).

Wood A., Athenae Oxonienses: An Exact History of All the Writers and Bishops who Have Had Their Education in the University of Oxford. To which are Added the Fasti, Or Annals of the Said University, 5 vols. (London: 1813-1820).

\section{Secondary Sources}

Amorim P.A.S., A Política externa de D. Sebastião: Portugal na Cristandade às vésperas de Alcácer-Quibir, MA thesis (University of Lisbon: 2019).

Attreed L., "Friends in Need or in Deed? Anglo-Portuguese Relations in the Fifteenth Century", Mediterranean Studies 8 (1999) 143-156.

Bagrow L., History of Cartography, rev. R.A. Skelton (New Brunswick - London: 1985). Baños-Garcia A.V., D. Sebastião: Rei de Portugal (Lisbon: 2006).

Barbosa de Machado D., Memorias para a História de Portugal: Que Conprehendem O Governo del Rey D. Sebastião, 4 vols. (Lisbon: 1736-1751).

Blanshard A.J.L. - Sowerby T.A., “Thomas Wilson's Demosthenes and the Politics of Tudor Translation", International Journal of the Classical Tradition 12, 1 (2005) 46-80. 
Brearley M., Hugo Gurgeny: Prisoner of the Lisbon Inquisition (London: 1947).

Carles N.R. de (ed.), Early Modern Diplomacy, Theatre and Soft Power: The Making of Peace (London: 2016).

Chapman A.B.W., "The Commercial Relations of England and Portugal, 1487-1807", Transactions of the Royal Historical Society 1 (1907) 157-179.

Correia F.S., "Os Velhos Hospitais da Lisboa Antiga", Revista Municipal 2, 10 (Lisbon: 1941) $3^{-13}$.

Croft P., "English Mariners Trading to Spain and Portugal, 1558-1625", Mariner's Mirror 69 (1983) 251-266.

Croft, P., "Trading with the Enemy 1585-1604", The Historical Journal 32, 2 (1989) 281-302.

Croft W., Historical Account of Lisbon College (Barnet: 1902).

Cruz M.A.L., D. Sebastião (Lisbon: 2006).

Cunha M.S., "A questão jurídica na crise dinástica”, in Mattoso J. (ed.), História de Portugal: no Alvorecer da Modernidade (Lisbon: 1997) 452-559.

Ebert C., "European Competition and Cooperation in Pre-Modern Globalization: 'Portuguese' West and Central Africa, 1500-160o', African Economic History 36 (2008) 53-78.

Eldred J., “'The Just will Pay for the Sinners': English Merchants, the Trade with Spain, and Elizabethan Foreign Policy, 1563-1585", Journal for Early Modern Cultural Studies 10,1 (2010) $5^{-28 .}$

Games A., The Web of Empire: English Cosmopolitans in an Age of Expansion, 1560-1660 (Oxford: 2008).

Hair P.E.H., The Founding of the Castelo de São Jorge da Mina: An Analysis of Sources (Wisconsin: 1994).

Magalhães J.R., “D. Sebastião”, in Mattoso J. (ed.), História de Portugal: no Alvorecer da Modernidade (Lisbon: 1997) 449-46o.

Morales O.R., Review of O'Connor T., Irish Voices from the Spanish Inquisition: Migrants, Converts and Brokers in Early Modern Iberia, trans. M.J. Sánchez-de-Nieva SEDERI 27 (2017) 269-272.

Newitt M. (ed), The Portuguese in West Africa: 1415-1670: A Documentary History (New York: 2010).

Oliveira S., “The Intolerable Business': Religion and Diplomacy under Elizabeth's Rule”, SEDERI 26 (2016) 159-174.

Polónia A., "European Seaports in the Early Modern Age: Concepts, Methodology and Models of Analysis", Cahiers de la Méditerranée 80 (2010) 17-39.

Prestage E., "The Anglo-Portuguese Alliance", Transactions of the Royal Historical Society 17 (1934) 69-100.

Protásio D.E., $2^{\circ}$ Visconde de Santarém (1791-1856): Uma Biografia Intelectual e Política (Lisbon: 2018). 
Santarém M.F. de Barros, Visconde de, Demonstração dos Direitos que tem a Coroa de Portugal sobre os Territórios situados na Costa Occidental D'Africa (Lisbon: 1855).

Santarém M.F. de Barros, Visconde de, Quadro elementar das relações politicas e diplomaticas de Portugal: com as diversas potencias do mundo, desde o principio da monarchia portugueza até aos nossos dias, 18 vols. (Lisbon: 1842-1876).

Shaw L.M.E., The Anglo-Portuguese Alliance and the English Merchants in Portugal, 1654-1810 (Aldershot: 1998).

Tawney R.H., "Introduction", in Wilson T., A Discourse upon Usury (London: 1925).

Wernham R.B., Before the Armada: The Growth of English Foreign Policy 1485-1588 (London: 1966). 